\title{
Effort to Understanding God: Learn from Stanley J. Samartha
}

Firman Panjaitan

Sekolah Tinggi Teologi Tawangmangu, Karanganyar. Indonesia

Email:panjaitan.firman@gmail.com

\begin{abstract}
The religious concept of God has essentially "killed" the real existence of God. The understanding of God has been narrowed through religious dogmas so that God no longer lives universally but is limited to religious dogmas that try to live it in its own religious way. Departing from this problem, this article aims to discuss efforts to find God who lives in the existence of human life. By using literature studies, especially examining Samartha's views on the power of syncretism to build an attitude of pluralism, the findings are that syncretism is a means to animate universal values in religion. Syncretism is the power to foster synergy between culture and religion, so as to form a grounded contextual understanding of the rules of the good life. Likewise with God. Through contextualization based on syncretism, God who has been killed by religious dogmas is brought back to life, so that it can greet life in accordance with the context in which God lives. God is seen universally and at the same time becomes a solid foundation for every religion in the world.
\end{abstract}

\section{Article History:}

Received: 4 May 2021

Accepted: 4 February 2022

Keywords:

Contextual;

God;

Stanley J. Samartha;

Syncretism.

\section{Introduction}

The condition of diversity in Indonesia is very pluralistic. Christianly, this raises three attitudes in responding to religious plurality, namely first, exclusivism, which teaches that Jesus Christ is the only way of salvation, and this attitude negates respect for religions outside Christianity. Second, inclusivism, which is the development of the first model after Christianity has encountered other religions. This model says that salvation can be achieved in various ways, but in the end Jesus Christ is still seen as the only norm that can lead humans to true salvation. The inclusivism model recognizes the universality of salvation and maintains the centrality of the Jesus Christ (Christ even) which is seen as the only norm for salvation. Third, pluralism, which emphasizes the understanding that salvation can be achieved in many ways. In contrast to the second model, pluralism places the center of salvation as universal God because God is seen as a reality that can be understood through various perceptions. Although acknowledging that the centrality of salvation is in the universal God, this paradigm emphasizes that 
Christianity does not have to eliminate Jesus Christ as its normative source, but its position of normativeness cannot be forced on the environment outside Christianity. ${ }^{1}$

From this description, we can see that religious pluralism is an existing reality and its existence cannot be avoided. On the one hand, this pluralism can be a strength for the community, because each religion can dialogue, share experiences in comparative studies of their religious teachings and norms and can make positive contributions to other religions. But on the other hand, the problem of religious pluralism can become a crucial problem if the existence of religious pluralism is not taken seriously. This happens because every religion wants to develop itself and its teachings well, so that the adherents of that religion can live by the rules and norms of that religion. Every religion must have an attitude of struggle for life and exclusive strength to develop and defend itself, its norms and teachings. This condition must be considered legitimate and positive, as long as these teachings and norms are systematically applied to each of its adherents. If this is well developed in each religion and its adherents, then this will be a major force to encourage inter-religious dialogue on the basis of mutual respect for each of the teachings and norms developed by each of the different religions.

But if this understanding is not developed properly, the religious pluralism will in turn into a terrible problem. This problem will arise and develop into a negative one when every religion is allowed and even suggested by its religious leaders to develop in an exclusivity dimension. The development of the exclusivity dimension of each religion will result in religions starting to shift the orientation of the development of their teachings and norms, not only to adherents of that religion but also to adherents of other religions. It means, on the one hand, the religion will invite its people to obey its norms and teachings, but on the other hand, the religion will also try to spread and impose its teachings and norms on adherents of other religions. Thus, each religion no longer tries to respect the existence of other religions, but wants to seize and dominate one another. This condition will result in religious pluralism, which was initially positive because it encourages each religion and its adherents to live side by side and respect each other, will shift towards conflict between religions with high intensity. The problems are more complex if we want to see the problem of pluralism in a more universal perspective, where pluralism not only shows religious diversity but can be described as a situation where various

\footnotetext{
${ }^{1}$ E.G. Singgih, Berteologi Dalam Konteks: Pemikiran-Pemikiran Mengenai Kontekstualisasi Teologi Di Indonesia (Jakarta-Yogyakarta: BPK Gunung Mulia-Kanisius, 2000), 70-73.
} 
religions, cultures and different ideologies appear simultaneously in the community and their existence. This pluralistic nature cannot be ignored, so we can say that the religious pluralism is only part of the larger problems concerning race, society and culture and existing social structures; although it is still recognized that religious pluralism is not an abstract conception because it is always directly related to human community. ${ }^{2}$

If this pluralistic situation is not taken seriously and each religion is allowed to live in its exclusivity, then the big question that will grow is, "Where is God?" Indeed, this question can be answered with a simple answer, "Of course God is in the understanding of each religion, culture and ideology". But this answer is not a satisfactory answer, because if God is only understood in each religion, culture and ideology, basically the existence of God has been minimized. ${ }^{3}$ God is only understood according to different versions of culture, religion and ideology. In another part this statement will lead us to the understanding that the concept of God according to religion, culture and ideology "A" certainly does not apply in the understanding of God according to religion or culture or ideology "B", "C", "X", "Z", and others. In this case, the existence of God has been limited by each culture or religion or ideology, and its means that the one who has the power to determine life is no longer God, but by culture, religion and ideology. The existence of God is placed in dependence on religion, culture and ideology which creates the conception of God. This is exacerbated when the conception of God according to a particular religion, culture and ideology is forced to be universally accepted by every different religion, culture and ideology. By building various conceptions of God, as has been done by every religion, culture and ideology to maintain its exclusivity, this actually has shown that God built into the conception is a dead God. Because this conceptual God will never speak in the universality of life. Its only speaks to the religion, culture and ideology that created him and does not speak to other religions, cultures and ideologies, even though they also live in the same world and life. If this situation to be maintained and even developed, then the above question becomes actual again with the addition of: Where is God (especially The Real God)? Where is the living God who greets life? ${ }^{4}$

This article seeks to make a theological reconstruction in an effort to find God, The Real God, who lives and greets life. The presentation of this paper will refer to the theological

\footnotetext{
${ }^{2}$ Eeuwout Klootwijk, Commitment and Opennes: The Interreligious Dialogue and Theology of Religions in the Work of Stanley J. Samartha (Zoetermeer: Uitgeverij Boekencentrum B.V., 1992), 72.

${ }^{3}$ Thio Christian Sulistio, "Evaluasi Terhadap Teologi Pluralisme Agama Stanley Samartha," Veritas: Jurnal Teologi dan Pelayanan 10, no. 2 (2009): 239-257.

${ }^{4}$ Ibid.
} 
understandings that have been developed by Stanley J. Samartha, especially regarding his views on syncretism. Because the focus of this article lies in exploring the meaning of syncretism according to Samartha, of course this article will not talk about Samartha at length. It must be admitted that the main concern of a Samartha lies in his concern to build dialogue in the midst of pluralism. ${ }^{5}$ Indeed, this article will discuss several views of Samartha's theology, but this allusion will not be too deep because I am worried that the focus of the problem will be shifted to issues surrounding other views of Samartha's theology. For this reason, it is necessary to define the problem clearly.

The discussion in this article uses qualitative methods, especially literature research approach. First step, I describe an object, phenomenon or social setting as outlined in narrative writing. ${ }^{6}$ The next step, using the data collection, I try to collect data from literary sources that are correlated with the problem and subject to be analyzed. ${ }^{7}$ Data analysis was carried out by presenting the object under study in the form of a narrative description for interpretation, both culturally, socially and biblically hermeneutic. ${ }^{8}$ After the analysis is carried out on the data obtained from various literary sources, a conclusion is drawn up as well as a recommendation for the formation of efforts to theology in the pluralist context in Indonesia.

\section{Samartha And His Theology}

\section{The Formation of Samartha Theology}

Klootwijk describes the development of Samartha's theological views into what can be described as follows: ${ }^{9}$

a. The phase of the encounter with Hendrik Kraemer.

Kraemer, in Tambaran - India, developed a form of mission theology. In his view, Kraemer argues that there is a peculiarity of the biblical message. This uniqueness lies in Biblical Realism which is seen as a radical theocentric character as well as being the starting point which

\footnotetext{
${ }^{5}$ J. Robert Phillips, John Hick, and Paul Knitter, "The Myth of Christian Uniqueness: Toward a Pluralistic Theology of Religions," Buddhist-Christian Studies 12 (1992): 295.

${ }^{6}$ Albi Anggito and Johan Setiawan, Metodologi Penelitian Kualitatif (Sukabumi: CV Jejak, 2018), 11.

${ }^{7}$ Abayomi Alase, "The Interpretative Phenomenological Analysis (IPA): A Guide to a Good Qualitative Research Approach," International Journal of Education and Literacy Studies 5, no. 2 (2017): 9.

${ }^{8}$ Aishath Nasheeda et al., "Transforming Transcripts Into Stories: A Multimethod Approach to Narrative Analysis," International Journal of Qualitative Methods 18 (2019): 1-9.

${ }^{9}$ Klootwijk, Commitment and Opennes: The Interreligious Dialogue and Theology of Religions in the Work of Stanley J. Samartha, 58-68.
} 
becomes the basis and criteria for all thoughts on Christianity and Christian theology. The Bible must be seen as a form of testimony of the Prophets and Apostles, which has unique characteristics, namely: radically religious, radically ethical, and radically theocentric. Through this understanding, an understanding of the prophetic message of the Bible is developed, where the message emphasizes the effort to evaluate all religions in the light of Christ because religions outside Christ are seen as religions that have a totalitarian character and are dominated by exclusive forms of thought. In this case Kraemer emphasized that non-Christian religions are bad so that Christianity must give witness to other religions. Kraemer places great emphasis on the revelation of God in Jesus Christ, so that the existence of Christ is normative for Christianity in dealing with human conditions. ${ }^{10}$

It is quite obvious that Kraemer has drawn an exclusive line in his theological view. For Kraemer, Christ is normative. Christ is the only way of salvation so that every religion needs to be evaluated and enlightened by Christ. The understanding of Christ as normative greatly influenced Samartha's theology. ${ }^{11}$ Samartha admits that the revelation of God in Christ is the only source and criterion in Christian faith. But in an exclusive position, Samartha is at odds with Kraemer. Samartha did not take the exclusive path, so Jan Jongeneel, according to Klootwijk, said that Kraemer and Samartha were seen as two conflicting/incompatible brothers. ${ }^{12}$ On the one hand they have similarities in viewing Christ as the only norm in Christianity, but on the other hand, especially in matters of orientation and study of nonChristian religions, both in their approaches and solutions, they really have very different. For Samartha, Kraemer's mission theology must be viewed as an abandoned position in Christian theology.

b. The phase of the encounter with Paul D. Devanandan.

In his meeting with Devanandan, Samartha came across a view that really respects other cultures and religions outside Christianity. He deeply respects and appreciates Devanandan as a person who has developed a new form of evangelization that emphasizes that redemption in

\footnotetext{
${ }^{10}$ Gerald H. Anderson, "Book Review: An Introduction to the Theology of Religions: Biblical, Historical, and Contemporary Perspectives," International Bulletin of Missionary Research 29, no. 1 (2005): 51-52.

${ }^{11}$ Gerald H. Anderson, "Book Review: An Introduction to the Theology of Religions: Biblical, Historical, and Contemporary Perspectives": 51-52.

${ }^{12}$ Klootwijk, Commitment and Opennes: The Interreligious Dialogue and Theology of Religions in the Work of Stanley J. Samartha, 60 .
} 
Christ should bring Christian understanding towards a respectful appreciation for other religions. Devanandan also developed the process of inter-religious dialogue, but the central point of this dialogue did not lie in the academic comparison of the systems of thought of religions, but rather he placed the central point of the dialogue on the basis of human values. Devanandan also saw that the presence of Jesus was to bring universal prosperity, for all people. According to Samartha, Devanandan has fostered an inclusive view towards religions, although the weakness still appears to lie in the primacy of Christ which is seen as transcending all religions (such as Kraemer and Karl Barth). ${ }^{13}$ The encounter between Samartha with Devanandan prepares Samartha for dialogue with other religions. But in subsequent developments Samartha surpasses Devanandan, because Samartha is no longer at an inclusive level but has stepped into a pluralist level.

c. The phase of the encounter with Madathilparampil Mammen Thomas.

The starting point of Thomas is Jesus Christ as the revelation of God, a real human being who wants to build new human values in the world. The theological view of Thomas put Christ at the center of Christian theology by directing his theological orientation to the world. ${ }^{14}$ However, it must be underlined that Thomas, regarding the center of Christian theology that is in Jesus Christ, also has the aim that this becomes the most important criterion in evaluating to all religions in this world, including Christianity. The new man in Christ became the main benchmark in building his theological outlook, especially when Thomas realized that he was dealing with a secular culture. Therefore Thomas can also be classified as a theologian who still has an inclusive view. But the influence of Thomas to Samartha in particular was concerned with the fact that theology and theologians, today, are not only dealing with theological questions but must also pay very serious attention to the development of this secular world. Therefore, in the development of his dialogue Samartha always considers all forms of development of the secular world-view in every description of his thoughts systematically to create dialogue between religions and theology of religions.

${ }^{13}$ S. J. Samartha, "Paul David Devanandan (1901-1962)," International Review of Mission 52, no. 206 (1963): 182190.

${ }^{14}$ Anderson, "Book Review: An Introduction to the Theology of Religions: Biblical, Historical, and Contemporary Perspectives.” 
In the three phases, we see that Samartha's theological mindset is very much influenced by the three theologians above, especially regarding the point of departure of his theology which emphasizes Jesus Christ. For Samartha, Jesus Christ is seen as determining Christian life and also emphasized that this existence (normative for Christianity) should not be generalized to others, because Christ does not determine for non-Christians. This is a pluralist view, which distinguishes Samartha from the three figures above.

Samartha so different from the three figures above, because Samartha also based his theological development through the teachings of Vedanta, especially regarding Advaita, which is packaged in Shankara's teachings. ${ }^{15}$ In summary, it can be described that Advaita means "no dualism" which means denial of a reality or more than one reality. However, this teaching is not a monolithic teaching, which teaches that everything flows from one principle alone. The point of this teaching is about the absence of spiritual dualism, in the sense that there is nothing real, apart from the absolute spirit, namely Brahman. ${ }^{16}$ Brahman is seen as the only real thing, which is called sat, while the individual soul is Brahman appearing as an additional means, and the world is seen as a virtual form of Brahman whose existence is impermanent, so the world is seen as an empirical reality that is being outside the brahman, where something that is seen to be outside of Brahman is called a-sat. It must be emphasized that the meaning of virtual here does not mean non-existence or illusion, but what is meant by illusion is a reality, it does exist, but that reality is not a form of the deepest reality. Thus, if it is said that the world is a virtual form of Brahman, then the existence of the world does not mean it does not exist, but rather shows that the existence of the world is a reality that is relative in relation to the Brahman himself. So the existence of the world cannot be separated from the existence of Brahman. ${ }^{17}$

In himself, Brahman has two modes of existence, namely a higher form (para-rupa) which is without character, without form, without distinction and without limitation. These four things are commonly referred to as Nirguna, Nirakara, Nirvisesa and Nirupadhi, and in this form is called Nirguna Brahman. Whereas in a lower form, Brahman has characteristics or imposes restrictions, for the purpose of worshiping humans (apara rupa) and in this form is called Saguna Brahman. In the appearance of Brahman, which occurs in restriction, what is called the imaginary Brahman

${ }^{15}$ Harun Hadiwijono, Sari Filsafat India (Jakarta: BPK Gunung Mulia, 1989), 83-91.

${ }^{16}$ Ibid., 85.

${ }^{17}$ Klootwijk, Commitment and Opennes: The Interreligious Dialogue and Theology of Religions in the Work of Stanley J. Samartha, 160-171. 
(world) appearance is formed. Thus, if we want to see Brahman, what we will find is Saguna Brahman, as the creator of the earth, whereas when Brahman is seen from his own eyes, he is in the form of Nirguna Brahman. ${ }^{18}$

This view of Advaita, which is developed by Shankara, was used by Samartha to build his theology based on Jesus Christ as a manifestation of God's revelation. According to Samartha, Jesus Christ who has been inherited in culture can be said to be Saguna Brahman, and this means that Jesus Christ is a virtual appearance, which is not the deepest reality but his existence is always related to Nirguna Brahman, who is God. Thus, as Saguna Brahman, Jesus Christ is only normative for Christians. If Christ wants to be communicated with other cultures or religions, he must be elevated to the Nirguna Brahman level to removing virtual boundaries in Jesus Christ. As Nirguna Brahman, Jesus Christ can have universal value, because it is understood as a universal God. $^{19}$ The use of Indian culture, to understand Christianity, is Samartha's attempt to communicate Christianity in a dialogue. Thus, the theological dialogical effort developed by Samartha can be said to be a form of effort to build Christian theology in cultural and religious pluralism.

\section{Some of Constraints in Pluralism}

Klootwijk described that Samartha was aware of several obstacles to building dialogue in conditions of pluralism. ${ }^{20}$ These obstacles can be described as follows:

a. Triumphalism Barriers.

Triumphalism is described as a form of victory from one religion and at the same time eliminating the existence of other religions. This is a danger to world peace and disturbs the relationship between humans in a multi-religious society as well as an illustration of the disloyalty of human attitudes towards religious spirituality. ${ }^{21}$ Samartha emphatically stated that Christianity must reject this attitude if it is to build good relations with mankind in conditions

\footnotetext{
${ }^{18}$ Moses P.P. Penumaka, "Luther and Shankara: Two Ways of Salvation in the Indian Context," Dialog: A Journal of Theology 45, no. 3 (2006): 252-262.

${ }^{19}$ A A Yewangoe, Theologia Crucis Di Asia, vol. 53 (Jakarta: BPK Gunung Mulia, 2015), 115-116.

${ }^{20}$ Klootwijk, Commitment and Opennes: The Interreligious Dialogue and Theology of Religions in the Work of Stanley J. Samartha, 82-86.

${ }^{21}$ Claudia Rapp, "Contested Ground in Gaza: The Narrative of Triumphalist Christianity," in Geneses: A Comparative Study of the Historiographies of the Rise of Christianity, Rabbinic Judaism, and Islam, ed. John Tolan, lst Editio. (London: Routledge, 2019), 260.
} 
of a multi-religious society. Christianity must run in a spirit of interfaith dialogue and leave this triumphalism spirit.

\section{b. Relativism Barries}

There is Samartha's concern in his efforts to build a dialogue in religious pluralism, namely falling into a relativistic. Samartha describes a relativistic as an indiscriminate attitude that accepts every position as something that contains elements of truth. This attitude causes people to be less enthusiastic about doing religious struggles in order to find basic decisions. ${ }^{22}$ For Samartha, all religions are not the same. It is precisely through these differences that relationships based on critical attitudes and the desire to enrich each other between religions become very possible.

\section{c. Syncretism Barries.}

Syncretism is understood as pluralism, where it will actually bring people into a worse position. This was particularly pronounced by Visser 't Hooft, who said:

Syncretism, understood as the fabrication of a common world religion, a synthetical universal religion, is too artificial and leas to nowhere ... There he (Visser 't Hooft) tends to see pluralism as synonymous with syncretism. ${ }^{23}$

However, the understanding of syncretism itself is not as simple as what is written above. In its development, many experts want to make sense of the understanding of syncretism. As stated by Thomas by saying that syncretism and relativism are basically not a real threat to Christian churches, as long as Jesus Christ has always been placed at the center of life. Here Thomas revealed that the term "Christ as the center" approach to religious pluralism already shows "Christ-centered syncretism", in a sense, pluralistic interactions between religions, cultures and ideologies of Christ always work to relativize religion and culture. ${ }^{24}$

For Samartha, the notion of syncretism itself cannot be viewed simply. He revealed that, on the one hand, he agrees with Visser 't Hooft, who said that syncretism can be something

${ }^{22}$ John Kaufman, "Historical Relativism and the Essence of Christianity," Studia Theologica - Nordic Journal of Theology 70, no. 1 (2016): 4-21.

${ }^{23}$ Klootwijk, Commitment and Opennes: The Interreligious Dialogue and Theology of Religions in the Work of Stanley J. Samartha, 83-84.

${ }^{24}$ Ryan Scruggs, "Faith Seeking Understanding: Theological Method in Thomas Merton's Interreligious Dialogue," Journal of Ecumenical Studies 46, no. 3 (2011): 411-426. 
dangerous for faith, if syncretism is seen as a 'fruit-salad approach', which is trying to mix all elements of the understanding of faith in a world that is precisely will result in ambiguity about faith itself. In this case, syncretism can be seen as something that is dangerous for faith and religion. But, on the other hand, if syncretism is understood as a form of equality with contextualization, then this syncretism can be viewed positively and even useful for faith. Through the meaning of syncretism with this kind, Christ's position as the center of the Christian faith will never be shaken. In this respect Samartha differs from Thomas, who says that syncretism is "Christ-centered syncretism". According to Samartha, syncretism is "integration of various elements by the crucified and risen Lord". ${ }^{25}$

\section{Appreciation to Samartha}

\section{Critics to Samartha}

Samartha's view to respect syncretism, not as a fruit-salad approach, needs to be appreciated. However, it seems that Samartha did not take into account well, that the distance between the fruit-salad approach and the contextualized form of syncretism is very thin. If this effort is carried out carelessly, people will fall into the mixture of various elements of religion and culture so that this effort, in fact, will lead to the form of a fruit-salad approach. ${ }^{26}$ I see that Samartha's efforts to find Christ by using the Wedha book, lead to syncretism in the form of a fruit-salad approach, we can see it in Samartha's theory which views God and Jesus as Saguna and Nirguna Brahman. If this is not observed and treated with caution, the Christ who is found is Christ who united with Sidharta Gautama due to the influence and thought patterns of Buddha, not Christ of India. Whereas what Samartha meant in the contextualization of theology in India was to find Christ of India.

In this way, i reminded of the criticism of the Dalits who say that Samartha's study of efforts to contextualize theology in India tends to be Brahmin in nature. This cannot be accepted easily by the Dalits, who postscript are a group of people who are outside the Brahmin, Ksatria, Weisa and Sudra castes. From the protests and criticisms of the Dalits, I see that the human tendency in bringing up attitudes and views based on his group still pervades the Samartha mindset. Samartha has not yet been able to escape from the prison of his caste and, it

\footnotetext{
${ }^{25}$ Sulistio, "Evaluasi Terhadap Teologi Pluralisme Agama Stanley Samartha."

${ }^{26}$ E.G. Singgih, Dari Israel Ke Asia (Jakarta: BPK Gunung Mulia, 1982), 34-35.
} 
seems, Samartha has always set his sights on the ground based on his being in the hierarchy of society. If the Dalit accusations are true, then Samartha is in the hierarchy of society as the Brahmin or the Ksatria caste. ${ }^{27}$

If this really happens, the contextualization which is looking for Jesus of India cannot work well. This will be in vain, because Jesus is positioned as God on the side of the elite class and not God who lives with the outcast, forgotten and humiliated people. This also means that the Jesus who was found was Jesus who lived in the midst of a magnificent caste palace and took sides with every caste that was above as well as helped to perpetuate the existence of the hierarchy of society and was involved in colonization for the lower castes. Even though the Jesus referred to in the Bible is Jesus who lived and worked in the midst of people who were marginalized, outcast and humiliated. Thus, if he wanted to strive for a Jesus of India, Samartha had to abandon all forms of caste in himself and live with the Dalit community, who a marginalized, outcast and humiliated group of people among the caste hierarchy in Indian society, in order to find the real Jesus of India. Jesus of India must be found in the life of the 'lower' class of society in India, because God incarnate in Jesus, as proclaimed by the Bible, is God incarnate in an outcast, humiliated and oppressed society.

\section{The Contribution of Samartha}

The act of Samartha has done can be said to be the stretch of eastern people in facing the phenomenon of Western theology that is expanding to the eastern world. Through his theological studies, which depart from the understanding of Advaita, Samartha tries to penetrate the solid fortress that has been passed down by Western theology so far. Samartha wants to build a dialogue in a pluralistic society, not just dialogue between religions, even dialogue between religion and culture, by first eliminating prejudice against certain religions or cultures. Samartha did not depart from a-priori, but he departed from respect for existing religions and cultures. Here we can see that Samartha wants to build a dialogical-contextual theology with the understanding that the starting point is not from zero. ${ }^{28}$ Because in building his theology, Samartha still placed Christ as the center and normative for Christianity, but he also did not apply this normative thing to non-Christian groups. Even though, Singgih said that

\footnotetext{
${ }^{27}$ Penumaka, "Luther and Shankara: Two Ways of Salvation in the Indian Context."

${ }^{28}$ Singgih, Berteologi Dalam Konteks: Pemikiran-Pemikiran Mengenai Kontekstualisasi Teologi Di Indonesia, 75.
} 
in the contextualization frame Samartha's theological efforts were still closer to the subject of inculturation than liberation, ${ }^{29}$ I saw that these efforts could be used as a starting point for developing contextual theology based on liberation points by theologians who continue theology of Samartha.

In Samartha's view of the subject of syncretism, I find that Samartha is more agreeable when syncretism is seen as the same form of contextualization. It is shown through his efforts to build theology which also shows the attempt to identify theology into Indian culture. I see that this understanding of Samartha is close to understanding the meaning of early syncretism which meant to unite to face a common enemy. ${ }^{30}$ Thus syncretism does not viewed negatively but positively, especially if we want to give attention that in addition to the existence of an element of unity there are also efforts to reconcile conflicting opinions or beliefs. Thus the understanding of syncretism in Samartha is further developed in the sense of unifying cultural values to try to find new meanings from the existence of contextual faith in India.

In another statement, Samartha also shows his disapproval of the form of syncretism with the fruit-salad approach. If syncretism is seen as a form of fruit-salad approach, it does not contextualization but a form of accommodation between culture and religion. ${ }^{31}$ I do not agree if this accommodation model is used in an attempt to place Christ in culture, because with this model the existence of Christ and culture will be vague and have no meaning whatsoever in life. In this case I agree with Samartha, although not ignoring the negative meaning of syncretism, because I see that the existence of a culture will never be separated from the mixture of various external cultural influences that have come and entered the culture. Example of religion which is part of culture, especially Christianity. What is Christian? Isn't this also a religious development from Judaism towards the institutionalization of the ethical teachings that Jesus had delivered, so that a religion called Christianity was formed? Isn't it true that with this mixture, basically, Christianity is also a syncretic religion? Likewise with what is commonly referred to as Christian culture (Christendom), which is actually a Western culture that was inherited by the colonizers to the eastern world, and as a dominant culture, of course this culture can grow more rapidly along with the coercion of the nation. Thus, doesn't this show

\footnotetext{
${ }^{29}$ Singgih, Berteologi Dalam Konteks: Pemikiran-Pemikiran Mengenai Kontekstualisasi Teologi Di Indonesia, 76.

${ }^{30}$ Niels Mulder, Agama, Hidup Sehari-Hari Dan Perubahan Budaya, Jawa, Muangthai Dan Filipina (Jakarta: PT Gramedia Pustaka Utama, 1999), 9-10.

${ }^{31}$ Firman Panjaitan, "Membangun Teologi Pertanian Melalui Pembacaan Lintas Tekstual Injil Matius Dan Kosmologi Jawa," BONAFIDE: Jurnal Teologi dan Pendidikan Kristen 1, no. 1 (2020): 44-64.
} 
that Christian culture is synonymous with Western culture? Through this process it can also be said that Christian culture, which is synonymous with Western culture, must have been mixed with cultures outside Christianity, this proves that Christianity is also very syncretistic.

I agree with Samartha who views that a counter-culture is needed to deal with the expansion of Western culture to eastern culture, through Christian culture. This form of counter-culture must take root and actualize in local cultures, where all elements of eastern culture are used to explain and place Jesus Christ, who is the center of faith, into the local cultural context. The existence of Christ, which is all western, must be shifted and put into eastern culture so that Christ can live in eastern culture. This effort can occur if the syncretism of eastern culture and Christianity can work well and positively, in the sense that the combination of cultural elements with an understanding of Christ does not mean that the understanding of Christ and culture becomes blurred. Through this combination it is hoped that a synergy will emerge. The synergy between Christ and culture makes Christianity stronger because it is rooted in culture and is maintained by the culture. This is what Samartha has been trying to do.

\section{A Theological Reconstruction to Find The Living Lord}

In introduction, I have stated that if the condition of religious pluralism is not criticized so as to create and develop an exclusivity, God has been killed by every religion through religious conceptual teachings about God. God known as a conceptual God. The danger of this conceptual of God is the lack of meaning from God to life. God no longer speaks to life, because God can only speak to the religions that created him. This danger can be overcome if we are willing to seek the living God. The living God is not the result of exclusive religious products, nor is it a conceptual God, but a God who is extracted and rooted in culture. Samartha has tried this efforts. Through his positive study of syncretism Samartha wants to 'revive' God who has been buried in western culture and conceptions. Samartha saw that God in western culture and conceptions could never exist in eastern culture, because it did not match what was understood by the east. For this reason, eastern people must seek and find God who lives in their culture. These efforts can be done using a tool, namely syncretism. Through syncretism, humans can make dialogical efforts between faith, culture and religion that are built on the basis of 'sharing of love' so that each culture is respected for its existence and then each culture is incorporated 
into a communicative fellowship. A communicative form of fellowship allows a dialogue to emerge, where the dialogue that occurs in this fellowship appears as a result of an encounter. In this dialogical encounter, all aspects of life in culture are brought together and then used as a new force called synergy. This synergy will result in a new understanding of the new culture that is formed in the fellowship.

For the basis of the cultural encounter in the dialogical community is the sharing of love, efforts to bring Christ, who is the center of faith, together with eastern culture cannot be done by using Christ in a eastern conception. The Christ who is brought together is the Christ who is kenosis (emptying himself) and then incognito in human life, so the understanding of Christ must be understood as Christ from below. Thus, the encounter that occurs is 'Christ from below' meets 'the culture that is in the world', so the encounter is in the frame of equality and this allows respect for each culture and allows the emergence of a dialogical effort based on sharing of love. The existence of Christ really lives in the culture, addresses the culture and lives the culture and works in the culture. Christ's position embedded in the land of culture allows Christ to work according to his own will without having to follow religious rules and conceptions.

\section{Conclusion}

Efforts to revive God that has been buried in religious conceptions through cultural syncretism efforts may fall back into the conception created if this syncretism effort has been institutionalized by humans. However, if humans always want to see this danger in the frame of their consciousness, surely these institutionalization efforts will be eliminated, at least, minimized. If so, Christ's encounter with culture through syncretic efforts has revived God in the roots of culture. The conceptual God is replaced with a living God in the culture. A God from 'above' is replaced by a God from 'below'. The living God will work optimally, according to His own will, and always give strength to every culture, including religion, to foster a pluralist, because the living God is rooted in the roots of a pluralistic culture. Thus, the attitude of religious exclusivity has been replaced by a pluralist attitude because the God who is known is the God of culture, the living God and the God who is rooted and lives in life. 


\section{Bibliography}

Alase, Abayomi. "The Interpretative Phenomenological Analysis (IPA): A Guide to a Good Qualitative Research Approach." International Journal of Education and Literacy Studies 5, no. 2 (2017): 9. http://dx.doi.org/10.7575/aiac.ijels.v.5n.2p.9.

Anderson, Gerald H. "Book Review: An Introduction to the Theology of Religions: Biblical, Historical, and Contemporary Perspectives." International Bulletin of Missionary Research 29, no. 1 (2005): 51-52. https://doi.org/10.1177/239693930502900128.

Anggito, Albi, and Johan Setiawan. Metodologi Penelitian Kualitatif. Sukabumi: CV Jejak, 2018.

Hadiwijono, Harun. Sari Filsafat India. Jakarta: BPK Gunung Mulia, 1989.

Kaufman, John. "Historical Relativism and the Essence of Christianity." Studia Theologica - Nordic Journal of Theology 70, no. 1 (2016): 4-21. https://doi.org/10.1080/0039338X.2016.1172108.

Klootwijk, Eeuwout. Commitment and Opennes: The Interreligious Dialogue and Theology of Religions in the Work of Stanley J. Samartha. Zoetermeer: Uitgeverij Boekencentrum B.V., 1992.

Mulder, Niels. Agama, Hidup Sehari-Hari Dan Perubahan Budaya, Jawa, Muangthai Dan Filipina. Jakarta: PT Gramedia Pustaka Utama, 1999.

Nasheeda, Aishath, Haslinda Binti Abdullah, Steven Eric Krauss, and Nobaya Binti Ahmed. "Transforming Transcripts Into Stories: A Multimethod Approach to Narrative Analysis." International Journal of Qualitative Methods 18 (2019): 1-9. https://doi.org/10.1177\%2F1609406919856797.

Panjaitan, Firman. "Membangun Teologi Pertanian Melalui Pembacaan Lintas Tekstual Injil Matius Dan Kosmologi Jawa." BONAFIDE: Jurnal Teologi dan Pendidikan Kristen 1, no. 1 (2020): 44-64. https://doi.org/10.46558/bonafide.vlil.8.

Penumaka, Moses P.P. "Luther and Shankara: Two Ways of Salvation in the Indian Context." Dialog: A Journal of Theology 45, no. 3 (2006): 252-262. http://dx.doi.org/10.1111/j.15406385.2006.00275.x.

Phillips, J. Robert, John Hick, and Paul Knitter. "The Myth of Christian Uniqueness: Toward a Pluralistic Theology of Religions." Buddhist-Christian Studies 12 (1992): 295. https://doi.org/10.2307/1389992.

Rapp, Claudia. "Contested Ground in Gaza: The Narrative of Triumphalist Christianity." In Geneses: A Comparative Study of the Historiographies of the Rise of Christianity, Rabbinic Judaism, and 
Islam, edited by John Tolan, 260. 1st Editio. London: Routledge, 2019.

Samartha, S. J. "Paul David Devanandan (1901-1962).” International Review of Mission 52, no. 206 (1963): 182-190. https://doi.org/10.1111/j.1758-6631.1963.tb02443.x.

Scruggs, Ryan. "Faith Seeking Understanding: Theological Method in Thomas Merton's Interreligious Dialogue." Journal of Ecumenical Studies 46, no. 3 (2011): 411-426. https://www.academia.edu/38400462/Faith_Seeking_Understanding_Theological_Meth od_in_Thomas_Mertons_Interreligious_Dialogue.

Singgih, E.G. Berteologi Dalam Konteks: Pemikiran-Pemikiran Mengenai Kontekstualisasi Teologi Di Indonesia. Jakarta-Yogyakarta: BPK Gunung Mulia-Kanisius, 2000.

_- D Dari Israel Ke Asia. Jakarta: BPK Gunung Mulia, 1982.

Sulistio, Thio Christian. "Evaluasi Terhadap Teologi Pluralisme Agama Stanley Samartha." Veritas: Jurnal Teologi dan Pelayanan 10, no. 2 (2009): 239-257. https://doi.org/10.36421/veritas.vl0i2.216.

Yewangoe, A A. Theologia Crucis Di Asia. Vol. 53. Jakarta: BPK Gunung Mulia, 2015. 